IFAS Extension

\title{
Water Quality and the Effectiveness of Pesticides'
}

\author{
F. M. Fishel ${ }^{2}$
}

\section{Introduction}

Pesticide applicators do not usually blame the mix for a pest control failure. Rather, the applicator will check if the correct pesticide was chosen for the job, if the pest was misidentified, if application equipment was properly calibrated, or if there was pesticide resistance. However, pesticide applicators should be aware that water quality can play a role in the efficacy of a pesticide treatment. Some pesticides lose their effectiveness when mixed with water that contains suspended or dissolved solids. This publication discusses how water quality affects pesticide mixes.

Water is the most commonly used carrier for diluting pesticides applied as sprays. Water is an effective solvent for many pesticides and enables small amounts of pesticides to be applied uniformly over large areas. Floridians rely heavily on water derived from underground aquifers for many uses, including diluting pesticides.

\section{Florida's Groundwater}

Most of the state's groundwater is contained in the Floridan aquifer, which underlies the majority of the state's land area and is characterized by thick, porous layers of limestone. However, Florida's aquifers do not contain water in pure form. Water from these aquifers ranges greatly in concentration of dissolved solids.

Dissolved solids are minerals contained in the water, dominated by the cations calcium, magnesium, sodium, and potassium. A common term to describe dissolved solids in water is "hardness." Hardness is most commonly expressed as milligrams of calcium carbonate per liter. Water containing calcium carbonate at concentrations below $60 \mathrm{mg} / \mathrm{l}(\mathrm{ppm})$ is generally considered soft; $60-120 \mathrm{mg} / \mathrm{l}$ is moderately hard; $120-180 \mathrm{mg} / \mathrm{l}$ is hard; and more than 180 $\mathrm{mg} / \mathrm{l}$ is very hard. According to the U.S. Geological Survey (USGS), dissolved solids concentrations vary from less than $25 \mathrm{ppm}$ to more than 25,000 ppm in the Upper Floridan aquifer (Figure 1). The chemical characteristics of water can greatly affect the efficacy of many pesticides.

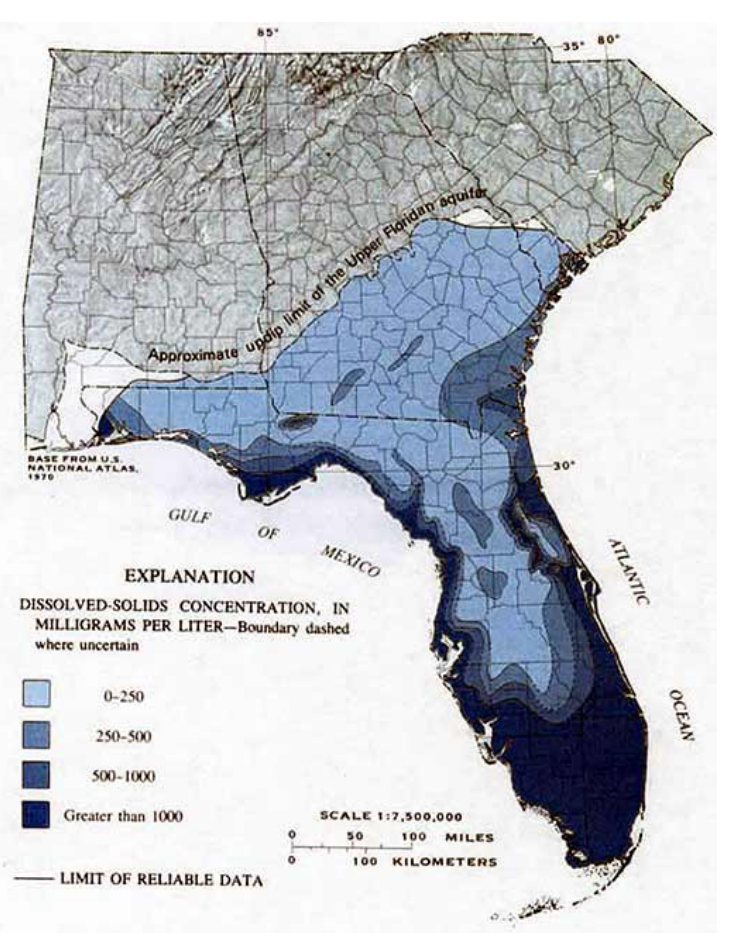

Figure 1. Dissolved solids concentrations of water from the Upper Floridan aquifer. Credits: USGS

1. This document is PI245, one of a series of the Agronomy Department, Florida Cooperative Extension Service, Institute of Food and Agricultural Sciences, University of Florida. Original publication date April 2013. Please visit the EDIS website at http://edis.ifas.ufl.edu.

2. F. M. Fishel, professor, Agronomy Department, and director, Pesticide Information Office; Florida Cooperative Extension Service, Institute of Food and Agricultural Sciences, University of Florida, Gainesville, FL 32611. 


\section{Water's Effect on Herbicide Efficacy}

Several herbicides, including 2,4-D, dicamba, and glyphosate, are weak acids, meaning they have an overall negative charge. Because they have a negative charge, these herbicides can be influenced by hard water cations, which have a positive charge, or foliar fertilizers. 2,4-D, dicamba, and glyphosate have been shown to have reduced effectiveness when applied in water that contains increased levels of calcium, magnesium, and other cations. Because of the chemical makeup of these weak acid herbicides, strong complexes can form when mixed with hard water. Negatively charged pesticide molecules attach to the positively charged cations calcium and magnesium. Herbicides bound to calcium and magnesium provide very poor control because the herbicides have difficulty entering or moving within the plant.

Studies since the 1970s show that increasing ion concentration decreases glyphosate activity. These studies also show that this antagonism was overcome by adding ammonium sulfate to the spray solution. Some product labels recommend mixing ammonium sulfate (such as $1 \%-2 \%$ by weight or 8-17 pounds per 100 gallons of water) with their products to improve performance, particularly when hard water is present. Ammonium sulfate works because it immediately separates into $\mathrm{NH}_{4}^{+}$(ammonium) and $\mathrm{SO}^{-}$ (sulfate) when dissolved in water. The positively charged calcium and magnesium prefer to bind to $\mathrm{SO}^{-}$rather than the herbicides. Therefore, if hard water is suspected and ammonium sulfate is used, add the ammonium sulfate to the tank before adding the herbicide.

Suspended solids are materials such as silt, clay, and organic matter that settle to the bottom of the tank if the water is left undisturbed. This is most common when spray water is drawn from ponds or canals. Certain herbicides bind tightly to soil and sediment and organic matter in water; this process is known as adsorption. Once adsorbed, the herbicide becomes unavailable for plant uptake. Product label statements will alert the user if such potential problems exist (Figure 2). Also, the product's material safety data sheet may contain statements about an herbicide's affinity to soil. Pesticide applicators should not mix pesticides with visibly muddy or murky water. Use a glass jar to test standing water to see if suspended solids are present.
6.0 MIXING

Clean sprayer parts immediately after using this product by thoroughly flushing with water.

NOTE: REDUCED RESULTS MAY OCCUR IF WATER CONTAINING SOIL IS USED, OR USE OF VISIBLY MUDDY WATER OR WATER FROM PONDS AND DITCHES THAT IS NOT CLEAR.

Figure 2. Some pesticide product labels alert the user if the pesticide has reduced performance when mixed with muddy water. Credits: Crop Data Management System (CDMS)

\section{Water Testing}

If you need to know how your water may be affecting pesticide application, you can have your water tested or you can test it yourself. The UF/IFAS Analytical Services Laboratory provides water testing. The service includes testing for calcium, magnesium, and total carbonates, as well as suspended solids. For information about the laboratory, visit http://soilslab.ifas.ufl.edu/ESTL\%20Home.asp. Water testing kits are also readily available from commercial vendors. Many of these use test strips of color-changing sensitive paper. Prices range widely, depending on how elaborate the test is.

\section{Additional Information}

Fishel, F. M., and J. A. Ferrell. 2007. Water pH and the Effectiveness of Pesticides. PI-156. Gainesville: University of Florida Institute of Food and Agricultural Sciences. http:// edis.ifas.ufl.edu/pi193.

Johnson, R. H., and P. W. Bush. 1988. Summary of the Hydrology of the Floridan Aquifer System in Florida, and in Parts of Georgia, South Carolina, and Alabama. USGS. 1403-A. http://sofia.usgs.gov/publications/papers/pp1403a/.

Mueller, T. C., C. L. Main, M. A. Thompson, and L. E. Steckel. 2006. "Comparison of Glyphosate Salts (Isopropylamine, Diammonium, and Potassium) and Calcium and Magnesium Concentrations on the Control of Various Weeds." Weed Technol. 20 (1): 164-171.

Roskamp, J. M., G. S. Chahal, and W. G. Johnson. 2013. "The Effect of Cations and Ammonium Sulfate on the Efficacy of Dicamba and 2,4-D." Weed Technol. 27 (1): 72-77. 